\title{
KEPUASAN PASIEN PESERTA BPJS DI RUANG RAWAT INAP RSUD PEKANBARU
}

\author{
Andalia Roza ${ }^{1)}$, Putri Wulandini $S^{2)}$ \\ 1) Program Studi D III Keperawatan Universitas Abdurrab \\ Jl. Riau Ujung No. 73, Pekanbaru, Riau \\ andalia.roza@univrab.ac.id \\ 2) Program Studi D III Keperawatan Universitas Abdurrab \\ D III Keperawatan Universitas Abdurrab \\ Jl. Riau Ujung No. 73, Pekanbaru, Riau \\ Putri.wulandini@univrab.ac.id
}

\begin{abstract}
Social Security Administering Agency (BPJS) is a social insurance provider institution so that with social security, the financial risks faced by a person, whether due to entering the productive age, experiencing illness, accidents, and even death, will be taken over by an institution that provides social security . Customer satisfaction is a major indicator of the standard of a health facility and is a measure of service quality. This study aims to determine the description of patient satisfaction BPJS participants RSUD Petala Bumi Riau Province 2016. This study uses a type of quantitative research with research design used the researcher is descriptive. This research was conducted at Inpatient Room of Petala Bumi Hospital Riau Province. The sample of this research is the participant of BPJS who visited the inpatient room of Petala Bumi Hospital Riau Province. The sample technique used was accidental sampling, with two weeks' working time. The research instrument used for this research is a questionnaire. Data processing includes editing, coding, processing, cleaning, and tabulating. The data analysis is done gradually including univariate analysis. The result of the research shows that patient satisfaction of BPJS inpatients is not satisfied as much as 22 respondents (55\%). It is expected that this research can provide motivation to the hospital to improve the quality of service in treating BPJS patients without discriminating.
\end{abstract}

Key word : BPJS, Satisfaction

\section{ABSTRAK}

Badan Penyelenggara Jaminan Sosial (BPJS) merupakan lembaga penyelenggara jaminan sosial sehingga dengan adanya jaminan sosial, risiko keuangan yang dihadapi seseorang,baik itu karena memasuki usia produktif, mengalami sakit, mengalami kecelakaan, dan bahkan kematian, akan diambil alih oleh lembaga yang menyelenggarakan jaminan sosial. Kepuasan pelanggan adalah indikator utama dari standar suatu fasilitas kesehatan dan merupakan suatu ukuran mutu pelayanan. Penelitian ini bertujuan untuk mengetahui gambaran kepuasan pasien peserta BPJS RSUD Petala Bumi Provinsi Riau Tahun 2016. Penelitian ini menggunakan jenis penelitian kuantitatif dengan desain penelitian yang digunakan peneliti yaitu deskriptif. Penelitian ini dilakukan di Ruang rawat inap RSUD Petala Bumi Provinsi Riau. Sampel penelitian pada penelitian ini adalah pasien peserta BPJS yang berkunjung di ruang rawat inap RSUD Petala Bumi Provinsi Riau. Teknik sampel yang digunakan adalah accidental sampling, dengan waktu pengerjaan selama dua minggu. Instrumen penelitian yang digunakan untuk penelitian ini adalah berupa kuisioner. Pengolahan data meliputi editing, coding, processing, cleaning, dan tabulating. Analisa data dilakukan secara bertahap yang meliputi analisis univariat. Hasil penelitian didapat kan adalah kepuasan pasien peserta BPJS diruang rawat inap adalah tidak puas sebanyak 22 responden (55\%). Diharapkan dengan penelitian ini dapat memberikan motivasi kepada rumah sakit agar meningkatkan kualitas pelayanan dalam merawat pasien BPJS tanpa membeda-bedakannya.

Kata Kunci : BPJS, Kepuasan 


\section{PENDAHULUAN}

Kesehatan merupakan keadaan sejahtera dari tubuh, jiwa, serta sosial yang sangat mungkin setiap individu hidup produktif dengan cara sosial serta ekonomis. Dengan kesehatan ini setiap individu dapat melaksanakan aktivitas sebagai makhluk ciptaan Tuhan Yang Maha Esa sehingga dapat hidup produktif baik secara sosial maupun ekonomis (Soejoeti, 2005).

Dalam mengatur masalah kesehatan diperlukan suatu badan khusus yang bertanggung jawab dalam menyelenggarakan jaminan kesehatan, dimana badan tersebut harus memberikan mutu pelayanan yang baik agar dapat tercapainya kepuasan pelayanan (Soejoeti, 2005).

Organisasi Kesehatan Dunia mendorong seluruh negara mengembangkan jaminan kesehatan untuk semua penduduknya (Universal Health Coverage). Dengan jaminan kesehatan tersebut semua penduduk di negara yang mengembangkan jaminan kesehatan ini termasuk peserta jaminan kesehatan (P. L. I. B. Kesehatan, 2014).

Di Indonesia, pada tanggal 1 Januari 2014 telah didirikan suatu Badan Penyelenggara Jaminan Sosial Kesehatan yang selaras dengan tujuan Organisasi Kesehatan Dunia dalam mengembangkan jaminan kesehatan untuk semua penduduk. BPJS Kesehatan ini merupakan badan hukum yang dibentuk untuk menyelenggarakan program kesehatan (Hartati, 2015).

Badan Penyelenggara Jaminan Sosial (BPJS) merupakan lembaga penyelenggara jaminan sosial sehingga dengan adanya jaminan sosial, risiko keuangan yang dihadapi seseorang,baik itu karena memasuki usia produktif, mengalami sakit, mengalami kecelakaan, dan bahkan kematian, akan diambil alih oleh lembaga yang menyelenggarakan jaminan social (Indonesia, 2013).

Rumah sakit sebagai salah satu fasilitas pelayanan kesehatan diharapkan dapat memberikan pelayanan yang efektif, efisien, dan dituntut untuk memberikan informasi kesehatan yang tepat dalam pelayanan kesehatan dan menghasilkan data yang akurat. Di dalam penyelenggaraan pelayanan publik, masih banyak dijumpai kekurangan, sehingga mempengaruhi kualitas pelayanan kepada masyarakat. Jika kondisi seperti ini tidak direspon, maka akan menimbulkan citra yang kurang baik terhadap rumah sakit sendiri . Mengingat jenis pelayanan yang sangat beragam, maka dalam memenuhi pelayanan diperlukan pedoman yang digunakan sebagai acuan bagi instansi di lingkungan instansi kesehatan. Pelayanan kesehatan adalah hak asasi manusia yang harus diselenggarakan oleh pemerintah dan swasta. Untuk mencapai kualitas yang diharapkan oleh masyarakat perlu adanya kerjasama dan usaha yang berkesinambungan (Asyhadie, 2008).

Badan Penyelenggara Jaminan Sosial atau BPJS merupakan lembaga yang dibentuk untuk menyelenggarakan Program Jaminan Sosial di Indonesia menurut Undang-undang Nomor 40 Tahun 2004 berisi tentang Sistem Jaminan Sosial Nasional, BPJS merupakan badan hukum nirlaba dan Undang- Undang Nomor 24 Tahun 2011 berisi tentang BPJS dibagi 2, BPJS Kesehatan dan BPJS Ketenagakerja, BPJS bertanggung-jawab langsung kepada Presiden, BPJS berwenang menagih iuran, menempatkan dana, melakukan pengawasan dan pemeriksaan atas kepatuhan Peserta dan pemberi kerja (Indonesia, 2013).

Kepuasan pelanggan adalah indikator utama dari standar suatu fasilitas kesehatan dan merupakan suatu ukuran mutu pelayanan kepuasan pelanggan yang rendah akan berdampak terhadap jumlah 
kunjungan yang akan mempengaruhi provitabilitas fasilitas kesehatan tersebut, sedangkan sikap karyawan terhadap pelanggan juga akan berdampak terhadap kepuasan pelanggan dimana kebutuhan pelanggan dari waktu ke waktu akan meningkat, begitu pula tuntutannya akan mutu pelayanan yang diberikan (FUZNA, 2014).

Pengukuran kepuasan pelanggan merupakan elemen penting dalam menyediakan pelayanan yang lebih baik, efisien dan lebih efektif. Tingkat kepuasan pelanggan terhadap pelayanan merupakan faktor penting yang mengembangkan suatu sistem penyediaan pelayanan yang tanggap terhadap keluhan pelanggan, meminimalkan biaya dan waktu serta memaksimalkan dampak pelayanan terhadap pasien (Syahputra, 2016).

BPJS Kesehatan harus memahami kebutuhan pelayanan kesehatan masyarakat yang dilayaninya dalam menentukan cara yang paling efektif menyelenggarakan pelayanan kesehatan bermutu. Rangkuti menyatakan bahwa pelayanan yang bermutu terbentuk dari lima dimensi Service Quality (Servqual) yaitu, kehandalan, daya tanggap, jaminan, empati, dan bukti fisik (Rangkuti, 2006).

Dengan banyaknya jumlah peserta BPJS Kesehatan secara nasional dan sebagai suatu sistem yang besar dan baru berlangsung dalam tempo yang relatif singkat, Dewan Jaminan Sosial Nasional (DJSN) melakukan monitoring dan evaluasi terhadap pelayanan BPJS Kesehatan, dimana terdapat permasalahan dalam pengaplikasiannya, banyak masyarakat yang belum tahu teknis mendapatkan pelayanan sesuai dengan aturan BPJS Kesehatan, sehingga banyak peserta BPJS Kesehatan yang mengeluhkan dengan sistem pelayanan rujukan berjenjang yang diterapkan BPJS Kesehatan (Syahputra, 2016).
Sistem pelayanan rujukan berjenjang ini juga menjadi tantangan yang kerap dihadapi pasien peserta BPJS Kesehatan di Rumah Sakit Umum Daerah Petala Bumi Provinsi Riau, dengan sistem ini pasien peserta BPJS Kesehatan sebelum berobat ke rumah sakit atau dokter spesialis wajib terlebih dahulu ke Fasilitas Kesehatan Tingkat Pertama (FKTP) yang telah ditunjuk yaitu puskesmas, dokter keluarga atau klinik untuk mendapatkan surat rujukan, hal ini berpengaruh dalam kepuasan pelanggan. Mutu pelayanan kesehatan sangat dipengaruhi oleh proses pemberian pelayanan.

Data tersebut diperkuat dengan hasil studi pendahuluan yang dilakukan oleh peneliti pada tanggal 1 Maret 2017 Rumah Sakit Umum Daerah Petala Bumi terhadap 10 pasien diperoleh hasil 7 orang pasien mengeluh dengan sistem pelayanan rujukan berjenjang yang diterapkan BPJS Kesehatan karena dengan sistem ini pasien yang ingin berobat ke fasilitas kesehatan tingkat kedua seperti rumah sakit atau dokter spesialis harus mendapatkan surat rujukan dari fasilitas kesehatan tingkat pertama terlebih dahulu seperti puskesmas, dokter keluarga atau klinik, dengan demikian pasien tidak bisa langsung berobat ke rumah sakit atau dokter spesialis, dan sisanya sebanyak 3 orang pasien merasa puas dengan adanya program BPJS Kesehatan.

Berdasarkan latar belakang diatas, peneliti tertarik meneliti tentang kepuasan pasien peserta BPJS di RSUD Petala Bumi Provinsi Riau Tahun 2017.

Tujuan penelitian ini adalah untuk mengetahui kepuasan pasien peserta BPJS di Rawat Inap RSUD Petala Bumi Provinsi Riau.

\section{METODE PENELITIAN}

Penelitian ini menggunakan jenis penelitian kuantitatif dengan desain 
penelitian yang digunakan peneliti yaitu deskriptif. Penelitian ini dilakukan di rawat inap RSUD Petala Bumi Provinsi Riau. Sampel penelitian pada penelitian ini adalah pasien peserta BPJS yang berkunjung di RSUD Petala Bumi Provinsi Riau. Teknik sampel yang digunakan adalah accidental sampling, dengan waktu pengerjaan selama satu minggu. Instrumen penelitian yang digunakan untuk penelitian ini adalah berupa kuisioner yang terdiri dari kuisioner yang berisi tentang kepuasan pasien peserta BPJS.

Pengolahan data merupakan bagian dari rangkaian kegiatan yang dilakukan setelah pengumpulan data. Untuk kemudahan dalam pengolahan data dipergunakan bantuan program komputer. Langkah-langkah pengolahan data meliputi editing, coding, processing, cleaning, dan tabulating. Analisa data dilakukan secara bertahap yang meliputi analisis univariat.

\section{HASIL DAN PEMBAHASAN}

Distribusi frekuensi responden berdasarkan umur adalah 17-25 tahun (remaja akhir) sebanyak 7 responden (17,5\%);26-35 tahun (dewasa awal) sebanyak 22 responden (55\%);36-45 tahun (dewasa akhir) sebanyak 9 responden (22,5\%) dan 46-55 tahun (lansia awal) sebanyak 2 responden (5\%).

Distribusi frekuensi responden berdasarkan jenis kelamin adalah laki-laki sebanyak 13 responden $(32,5 \%)$ dan perempuan sebanyak 27 responden $(67,5 \%)$.

Distribusi frekuensi responden berdasarkan pendidikan adalah SD sebanyak 6 responden (15\%); SMP sebanyak 2 responden (5\%); SMA sebanyak 23 responden $(57,5 \%)$ dan Perguruan tinggi sebanyak 9 responden $(22,5 \%)$.

Distribusi frekuensi rseponden berdasarkan pekerjaan adalah bekerja sebanyak 24 responden $(60 \%)$ dan tidak bekerja sebanyak 16 responden $(40 \%)$.
Distribusi Frekuensi Responden Berdasarkan Kepuasan Pasien BPJS terhadap pelayanan di Rawat Inap RSUD Petala Bumi Tahun 2017 adalah puas sebanyak 18 responden (45\%) dan tidak puas sebanyak 22 responden $(55 \%)$.

Dari hasil penelitian ini diketahui bahwa banyak responden di rawat inap merasa tidak puas terhadap pelayanan kesehatan yakni sebanyak $55 \%$ (22 responden). Berdasarkan pertanyaan dari kuisioner yang di bagikan oleh peneliti responden merasa sangat puas pada pertanyaan kuisioner tentang kecepatan perawat untuk memberikan bantuan ketika diperlukan yakni sebesar (82\%) dan pada pertanyaan tentang ketepatan dalam penyajian makanan yakni sebesar (82\%). Berdasarkan observasi yang dilakukan oleh peneliti pada saat melakukan penelitian memang pemberian makanan kepada pasien dilakukan sangat tepat waktu, baik itu makanan utama ataupun makanan cemilan, dan perawat di rumah sakit ini selalu cepat tanggap dalam melayani semua kebutuhan pasien. Responden merasa sangat tidak puas pada pertanyaan ke lima belas dan pertanyaan ke dua puluh empat, pertanyaan ini tentang kebisingan $(85 \%)$, berdasarkan pengamatan yang dilakukan oleh peneliti, kebanyakan pasien BPJS dirawat dikelas III atau bangsal, di ruangan ini kapasitas untuk satu kamar adalah sebanyak 6 pasien, inilah yang membuat rasa gaduh menjadi masalah pada rumah sakit ini.

Penelitian ini sejalan dengan penelitian yang dilakukan oleh Fakianti, dkk pada tahun 2015 yang berjudul Kualitas Pelayanan Dengan Kepuasan Pasien Peserta Bpjs Di Instalasi Rawat Inap Rsud Haji Makassar yang hasilnya mengatakan bahwa ada hubungan antara kepausan pasien BPJS terhadap Lingkungan Rumah Sakit dan Pelayanan Makanan (Fakianti, Kapalawi, \& Pasinringi, 2015). Ini pun sejalan dengan penelitian yang dilakukan oleh Khoiri \& 
Hermastutik yang berjudul Hubungan Mutu Pelayanan Keperawatan Dengan Kepuasan Pasien Pengguna Kartu BPJS Kesehatan di Puskesmas Mojowarno Kabupaten Jombang yang hasilnya terdapat hubungan yang signifikan terhadap pelayanan keperawatan dengan kepausan pasien BPJS (Fakianti et al., 2015).

Pasien baru akan merasa puas apabila kinerja pelayanan kesehatan yang diperolehnya sama atau melebihi dari apa yang diharapkannya dan sebaliknya, ketidakpuasan akan timbul apabila pelayanan kesehatan yang diperoleh tidak sesuai dengan harapan(Pohan, 2007). (Sinambela, 2010) menyatakan bahwa secara teoritis, tujuan pelayanan pubik pada dasarnya adalah memberi kepuasan pada masyarakat. Sehingga dalam mencapai kepuasan tersebut diperlukan kualitas pelayanan yang prima.

Menurut Nugroho

mengemukakan bahwa tenaga kesehatan merupakan pegawai inti dari rumah sakit. Hal ini didasarkan pada tujuan utama masyarakat berkunjung ke rumah sakit adalah untuk mendapatkan pelayanan kesehatan di lokasi tersebut. Dengan demikian keberadaan dokter, perawat, dan petugas lainnya pada rumah sakit akan terkait langsung dengan kepuasan pasien yang berobat atau berkunjung ke pelayanan kesehatan. Pelayanan petugas berhubungan dengan tugas para tenaga kesehatan di rumah sakit untuk menyelenggarakan kegiatan-kegiatan kesehatan sesuai dengan bidang keahlian dan atau kewenangan tenaga kesehatan yang bersangkutan mematuhi standar profesi dan menghormati hak pasien. Selain itu pelayanan petugas juga berkaitan dengan hubungan antarmanusia,yaitu antara pemberi layanan dengan pasien secara langsung. Dari hasil penelitian yang dilakukuan,diperoleh data yang menunjukkan bahwa sebagian besar merasa puas dengankecepatan perawat untuk memberikan bantuan ketika diperlukan oleh pasien (Fakianti et al., 2015).

Junadi (2007), mengemukakan yang mempengaruhi kepuasan terdiri dari 4 aspek salah satunya adalah, aspek ini dijabarkan dalam pertanyaan tentang lokasi rumah sakit, kebersihan, kenyamanan ruangan, makanan dan minuman, peralatan ruangan, tata letak, penerangan, kebersihan WC, pembuangan sampah, kesegaran ruangan. Wahyu Robby dalam penelitiannya therapeutic environment mengatakan, bahwa proses penyembuhan pasien juga dipengaruhi kenyamanan fisik pasien ketika berada di dalam ruang rawat inap. Kenyamanan fisik dapat distimulus melalui 4 indera kita, yaitu secara visual, auditorial, penciuman, dan indera peraba (kulit). Dilihat secara desain permainan warna interior, alunan suara musik atau gemericik air, harumnya ruang rawat inap, bersihnya bad untuk tidur pasien hingga suhu yang tidak panas, secara tidak langsung diharapkan memberikan kenyamanan pasien untuk sejenak melupakan penderitaan sakitnya. Ketidaknyamanan lingkungan fisik tanpa sadar atau disadari telah menyebabkan stres pada pasien. Bentuk ketidaknyamanan lingkungan fisik di rumah sakit dapat berupa kebersihan ruang yang tidak terjaga, suhu ruang terlalu panas, kebisingan yang mengganggu, serta penerangan yang menyebabkan silau atau intensitas penerangan yang rendah. Bila hal ini dibiarkan berlanjut terus-menerus dikhawatirkan akan berpengaruh negatif pada kualitas output kesehatan pasien (Robby \& Wahyu, 2006).

\section{SIMPULAN}

Berdasarkan hasil penelitian yang telah dilakukan dapat disimpulkan bahwa: responden tidak puas terhadap pelayanan yakni sebesar 55\% (22 responden) 
DAFTAR PUSTAKA

ABDILAH, A. D., \& RAMDAN, M. (2009). Hubungan karakteristik pasien dengan kepuasan pasien rawat jalan di puskesmas Sindang kerta Kabupaten Bandung Barat. Jurnal Kesehatan Kartika StikesA. Yani.

Asyhadie, Z. (2008). Aspek-aspek hukum jaminan sosial tenaga kerja di Indonesia. Rajawali Pers.

Djoko, W. (2014). Manajmen Mutu Pelayanan Kesehatan. Surabaya: Airlangga University Press.

Fakianti, A., Kapalawi, I., \& Pasinringi, S. A. (2015). KUALITAS PELAYANAN DENGAN KEPUASAN PASIEN PESERTA BPJS DI INSTALASI RAWAT INAP RSUD HAJI MAKASSAR.

FUZNA, U. E. (2014). Kepuasan Pasien BPJS (Badan Penyelenggara Jaminan Sosial) Terhadap Pelayanan di Unit Rawat Jalan (URJ) Rumah Sakit Permata Medika Semarang Tahun 2014. Skripsi, Fakultas Kesehatan.

Gerson, R. (1993). Measuring customer satisfaction. Crisp Learning.

Hartati, W. (2015). Kajian yuridis perubahan PT. Askes (PERSERO) menjadi Badan Penyelenggara Jaminan Sosial (BPJS) Kesehatan. Jurnal IUS, 3(9), 481-496. Indonesia, K. K. R. (2013). Buku Pegangan Sosialisasi Jaminan Kesehatan Nasional (JKN) dalam Sistem Jaminan Sosial Nasional. Pusat Pembiayaan Dan Jaminan Kesehatan Kementerian Kesehatan RI.

Jacobalis, S. (2000). Kumpulan tulisan terpilih tentang rumah sakit Indonesia dalam dinamika sejarah, transformasi, globalisasi, dan krisis nasional. Yayasan Penerbitan IDI.

Kesehatan, B. (2014). Panduan Layanan Bagi Peserta BPJS Kesehatan. Jakarta: Kementerian Kesehatan RI.

Kesehatan, K., \& Kesehatan, K. (2015).
Buku Saku FAQ (Frequently Asked Questions) BPJS Kesehatan. Kementerian Kesehatan RI.

Kesehatan, P. L. I. B. (2014). Panduan Praktis Sistem Rujukan Berjenjangee . Diakses Diakses, 20.

Listiani, I., \& Supratman, M. K. (2017). Hubungan Tingkat Pendidikan dan Penghasilan Pasien dengan Persepsi Pasien Tentang Mutu Pelayanan Kesehatan di Puskesmas Baki Kabupaten Sukoharjo. Universitas Muhammadiyah Surakarta.

Lumenta, B. (1989). Hospital: citra, peran, dan fungsi: tinjauan fenomena sosial. Kanisius.

Notoatmodjo, S. (1993). Pengantar pendidikan kesehatan dan ilmu perilaku kesehatan. Andi Offset.

Nursalam. (2011). Manajemen Keperawatan. Jakarta: Salemba Medika.

Peraturan Presiden, R. I. (2013). Peraturan Presiden RI No. 111 tahun 2013 tentang Perubahan atas Perpres No. 12 tahun 2013 tentang Jaminan Kesehatan. Tersedia Pada: < Http://www. Bkkbn. Go. Id.> [diakses 30 Desember 2013].

Pohan, I. S. (2007). Jaminan Mutu Layanan Kesehatan Dasar Dasar Pengertian dan Penerapan. Jakarta: EGC.

Rangkuti, F. (2006). Measuring Customer Satisfaction. Jakarta: Gramedia Pustaka Utama.

Robby, \& Wahyu. (2006). Mепи Paradigma Therapeuti.

Sinambela, L. . (2010). Reformasi Pelayanan Publik;Teori,Kebijakan dan Implementasi (Kelima). Jakarta: PT. Bumi Aksara.

Soejoeti, S. Z. (2005). Konsep sehat, sakit dan penyakit dalam konteks sosial budaya. Majalah Cermin Dunia Kedokteran, (149).

Syahputra, A. (2016). Hubungan Mutu Pelayanan BPJS Kesehatan Dengan 
Kepuasan Pasien Di Instalasi Rawat

Inap Kelas II Rumah Sakit Umum

Daerah Sekayu Tahun 2015. Karya
Tulis Ilmiah, Akademi Keperawatan Pemerintah Kabupaten Musi

Banyuasin. Dikutip. 